$12-2010$

\title{
Doug Ruthven and Jorg Karger: Their Individual and Collective Contributions to the Field of Zeolite Science and Engineering
}

Dhananjai B. Shah

Cleveland State University

Follow this and additional works at: https://engagedscholarship.csuohio.edu/encbe_facpub

Part of the Transport Phenomena Commons

How does access to this work benefit you? Let us know!

Publisher's Statement

The final publication is available at Springer via http://dx.doi.org/10.1007/s10450-010-9256-8

\section{Original Citation}

Shah, D. B. (2010). Doug Ruthven and Jörg Kärger: Their individual and collective contributions to the field of zeolite science and engineering. Adsorption, 16(6), 497 - 509. doi:10.1007/s10450-010-9256-8

\section{Repository Citation}

Shah, Dhananjai B., "Doug Ruthven and Jorg Karger: Their Individual and Collective Contributions to the Field of Zeolite Science and Engineering" (2010). Chemical \& Biomedical Engineering Faculty Publications. 84.

https://engagedscholarship.csuohio.edu/encbe_facpub/84

This Article is brought to you for free and open access by the Chemical \& Biomedical Engineering Department at EngagedScholarship@CSU. It has been accepted for inclusion in Chemical \& Biomedical Engineering Faculty Publications by an authorized administrator of EngagedScholarship@CSU. For more information, please contact library.es@csuohio.edu. 


\title{
Doug Ruthven and Jörg Kärger: Their individual and collective contributions to the field of zeolite science and engineering
}

\author{
Dhananjai B. Shah
}

\begin{abstract}
Prof. Doug Ruthven and Prof. Jörg Kärger are two giants in the field of zeolite science and engineering. Over their academic careers encompassing almost forty years each, they have contributed significantly to the advancement of fundamental understanding of adsorption and diffusion in zeolites as well as their industrial applications. The author, in the beginning of his academic career, had an opportunity to spend two years as a post-doctoral fellow in Prof. Ruthven's laboratory at the University of New Brunswick (1975-1977). This experience actually motivated me to spend my academic career in working in the field of zeolite adsorption and diffusion. Nearly thirty years later, I spent a year as a Gast Mercator Professor at the University of Leipzig in the laboratory of Prof. Kärger (20052006). These two opportunities at two different ends of my academic career provided me with unique perspectives to reflect on the important contributions made by Professors Ruthven and Kärger to the field of zeolite science and technology. This article summarizes my personal perspectives on the breadth and depth of their contributions.
\end{abstract}

Keywords Prof. D.M. Ruthven · Prof. J. Kärger ·

Adsorption · Diffusion · Zeolites · Adsorption processes

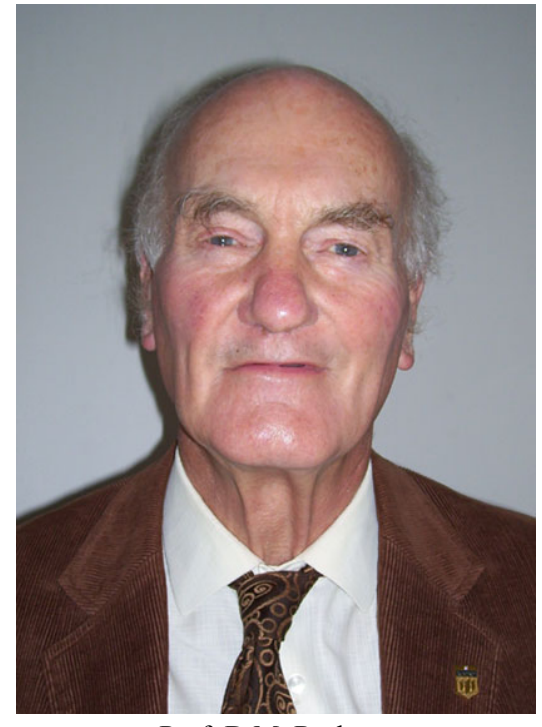

Prof. D.M. Ruthven

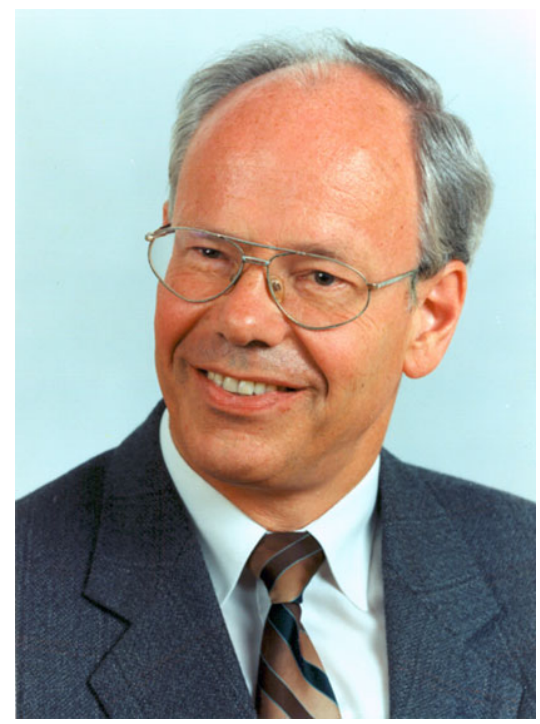

Prof. J. Kärger 


\section{Introduction}

Profs. Ruthven and Kärger are giants in the field of zeolite science and engineering. Both have made lasting contributions in various aspects of this field. Prof. Ruthven studied the adsorption and diffusion phenomena in zeolites with macroscopic techniques such as gravimetric, volumetric, chromatographic and zero length column (ZLC) methods. In these methods, an adsorbent-adsorbate system at equilibrium is perturbed and its response is monitored with respect to time by measuring a macroscopic property such as the weight of the sample or pressure or volume of gas space or gas phase concentration. A model is formulated that relates these changes in macroscopic properties with the internal movement of the molecules. The micropore diffusivity that characterizes this internal transport is then calculated from the measured response. Prof. Kärger, on the other hand, used a different approach and measured the internal transport rate directly with a microscopic method such as the Pulsed Field Gradient Nuclear Magnetic Resonance (PFG NMR) or more recently by mesoscopic techniques such as Infra-Red (IR) Spectroscopy and Interference Microscopy (IFM). Disagreement in values obtained by these two sets of methods for the same adsorbent-adsorbate systems led to significant collaboration between these two scientists over a span of three decades to reconcile these differences.

As these scholars approach their retirement, it is appropriate to look back on their stellar careers and gauge their individual as well as collaborative contributions to the overall field of zeolite science and engineering. Below, I present my personal perspectives on their contributions, why they have been so successful and provide a glimpse of their personal traits that have enabled to make such lasting contributions in the field.

\section{Prof. Doug Ruthven}

Doug was born in British India in 1938. He completed his undergraduate (BA, 1960), and graduate degrees (MA, 1963 and $\mathrm{PhD}, 1966)$ from Cambridge University in UK. He moved to the University of New Brunswick, Fredericton, Canada in 1966 and stayed there until 1995. He quickly rose through the academic ranks and was already a Professor when I joined him in 1975 as a post-doctoral fellow. Since 1995, he has been a professor at the Department of Chemical \& Biological Engineering at the University of Maine. He has been a long-term consultant to Exxon-Mobil and has co-authored three authoritative books on adsorption, diffusion in porous materials and pressure swing processes. In addition, he has published over 270 peer-reviewed journal papers and communications.

Prof. Ruthven's PhD research area was in the field of catalysis and reaction engineering. His early career at New
Brunswick saw him continue his research work in this area as his initial master's and doctoral students theses indicate. The topics included slurry phase catalysis, water gas shift reactors, catalytic hydrogenation, and Palladium Hydride catalysts for hydrogenation and dehydrogenation. Concurrently, he started studying adsorption and diffusion in A type of zeolites. Beginning with early seventies, he switched his focus completely on studying adsorption and diffusion in zeolites and their potential applications in industry.

Doug Ruthven is one of a very few scientists who have made lasting original contributions in all aspects of zeolites. He has worked in organic synthesis using zeolites, adsorption isotherm modeling, measurements and data analysis for a variety of adsorbent-adsorbate systems, kinetics of adsorption (modeling, developing new experimental techniques and experimental measurement), and modeling of fixed bed adsorbers and adsorption processes (pressure and temperature swing adsorption and simulated counter current adsorption processes). Each one of these areas is discussed in detail below.

\subsection{Use of zeolites in organic synthesis}

Prof. Ruthven did a limited amount of work on organic synthesis using zeolites. He and Dr. Risbood, a post-doctoral fellow during 1976-1977, reported two interesting cases of using shape selectivity of zeolites in organic synthesis. In one paper (Risbood and Ruthven 1978), they used the shape selective feature of a molecular sieve adsorbent to influence the course of a noncatalytic reaction. They cleverly used bromine adsorbed in 5A molecular sieve to selectively brominate the terminal double bond in an aliphatic side chain that penetrates the zeolite pore structure. In a second paper (Risbood and Ruthven 1979), they adsorbed $\mathrm{LiBH}_{4}$ on zeolites A and X and selectively reduced aldehydes in the presence of ketones. Aldehydes have critical diameters less than the size of the pore window of $5 \mathrm{~A}$ and hence can penetrate the pores of $5 \mathrm{~A}$. However, ketones possess critical diameters greater than the size of pore window of $5 \mathrm{~A}$ and are, therefore, effectively excluded from accessing the $\mathrm{LiBH}_{4}$.

\subsection{Adsorption isotherm modeling, measurement and data analysis}

In this area, Prof. Ruthven has made many notable contributions. He has measured adsorption isotherms for a variety of alkanes, alkenes, inert gases in A type zeolites, correlated data and analyzed them in a series of papers with Loughlin and Derrah. He proposed a new adsorption isotherm model based on statistical thermodynamics (Ruthven 1971, 1982). Prof. Ruthven and his students (Doetsch, Vavlitis, Graham, Goddard) have also measured adsorption isotherms 
of aromatics and large molecules such as triethylamine and tributylamine and cyclic compounds on large pore zeolites such as Faujasite, $\mathrm{X}, \mathrm{Y}$ and their $\mathrm{Na}, \mathrm{K}$ and $\mathrm{La}$ ion exchanged forms. With Cavalcante, he studied the adsorption of normal, branched and cyclic paraffins in silicalite, erionite and offretite. They used a variety of experimental techniques to measure adsorption isotherms such as gravimetric, chromatographic and headspace chromatography. Through a series of papers (Shah and Ruthven 1977; Haq and Ruthven 1986; Ruthven and Kumar 1979; Boniface and Ruthven 1985), Prof. Ruthven also popularized the use of chromatographic technique for measuring adsorption isotherms. In the use of chromatographic method, he used different perturbations such as pulse input (Shah and Ruthven 1977), step change (Ruthven and Kumar 1979) and sinusoidal input (Boniface and Ruthven 1985). They modified the method to not only measure equilibrium for one component but also for binary and ternary equilibrium measurements.

\subsection{Diffusion in zeolites}

In the seventies, Prof. Ruthven and his students focused on A type of zeolites. In the late seventies and early eighties, a gradual shift occurred from small pore A zeolites to large pore X, Y and Faujasite zeolites. They used both the gravimetric and chromatographic techniques for the study of adsorption and diffusion in zeolites. They measured responses of the adsorbent-adsorbate systems to different types of perturbations. The measurement of kinetics provided both the micropore diffusivities and the equilibrium capacity at steady state. They determined micropore diffusivities of $\mathrm{n}$ paraffins in A type of zeolites followed by diffusivities of larger molecules such as $\mathrm{C}_{8}$ aromatics in large pore zeolites. The initial studies were performed with crystals but later on pellets were used to delineate the effect of the presence of the binder. Dependence of micropore diffusivity on adsorbed phase concentration was studied for different systems. They also studied the effect of crystal size. Adsorption and diffusion of aromatics in $\mathrm{X}$ and $\mathrm{Y}$ type of zeolites was studied by liquid chromatography. His first book, Principles of Adsorption and Adsorption Processes, was published in 1984. In the late eighties (Eic and Ruthven 1988), Prof. Ruthven developed the zero length column (ZLC) technique to study diffusion in zeolites. The technique has found wide spread acceptance as one of the most useful experimental techniques in studying adsorption and diffusion in zeolites.

In the nineties, his collaboration with Brandani brothers began as they published a series of papers on the application of ZLC to expand its scope and the range of operation. The ZLC method was extended to study diffusion in liquid systems (Ruthven et al. 1993; Brandani and Ruthven 1995). Ruthven and his co-workers performed adsorption and diffusion studies using silicalite with larger molecules such as $\mathrm{C}_{8}$ aromatics (Ruthven et al. 1991; Eic and Ruthven 1989) and branched and cyclic hydrocarbons (Boulicaut et al. 1998). The method was applied to determine transport properties of mixtures (Jiang et al. 2002). They also extended the method to determine the adsorption equilibria for one component (Brandani et al. 2003) and binary systems (Brandani and Ruthven 2003). They analyzed the heat effects in ZLC (Brandani et al. 1998). Brandani et al. (1995) used tracer exchange ZLC to study self-diffusion in $5 \mathrm{~A}$ and $13 \mathrm{X}$ crystals. Brandani et al. (2000) also extended the use of ZLC under nonlinear conditions. The ZLC technique was also extended to study self-diffusion and counter diffusion of benzene and p-xylene in silicalite (Brandani et al. 2000).

While determining micropore diffusivities with the help of the macroscopic techniques Prof. Ruthven and his students used, it became apparent that these values were, in several cases, two to four orders of magnitude lower than those measured by Prof. Kärger's group using microscopic methods such as PFG NMR. A common tendency would have been to dismiss the results from the East German group. But, like a true scientist, Prof. Ruthven undertook a collaborative work with Prof. Kärger to understand the PFG NMR technique and to truly find reasons for such discrepancies. These collaborative work led to two joint papers on the comparison of zeolite diffusivities measured by macroscopic and microscopic techniques that are very well cited and a book published on the subject in 1992. This research collaboration has lasted for more than three decades.

\subsection{Adsorption column dynamics: simulation and modeling}

In the early seventies, Prof. Ruthven also initiated an elaborate research program on simulation and modeling of dynamics of adsorption column behavior. In a series of papers with Garg, Lee, Yoshida and Raghavan, the dynamic behavior of adsorption column was simulated under different limiting conditions such as macropore diffusion control (Garg and Ruthven 1974a) and micropore diffusion control (Garg and Ruthven 1974a, 1974b) under isothermal conditions. The behavior of nonisothermal adsorption columns was simulated as well (Ruthven et al. 1975; Ruthven and Lee 1981). They studied the effects of various factors on the adsorption column dynamics such as nonlinear equilibria (Garg and Ruthven 1973), rectangular isotherm (Yoshida et al. 1984) and combined effects of mass transfer and longitudinal diffusion (Garg and Ruthven 1975). The simulated results, in most cases, were verified by comparison with experimental data measured in the lab.

\subsection{Process applications}

Simultaneously, the research emphasis shifted towards applying adsorption principles to design pressure swing, tem- 
perature swing and simulated moving bed processes. Prof. Ruthven and his co-workers worked on many different industrial applications of adsorption. A series of papers was published (Raghavan et al. 1985; Hassan et al. 1985; Raghavan and Ruthven 1985; Farooq et al. 1988, 1989 and Farooq and Ruthven 1991) on simulation and modeling of PSA processes. The PSA process was analyzed for a trace component system (Raghavan et al. 1985; Hassan et al. 1985) as well as for bulk gas separation (Raghavan and Ruthven 1985). They investigated adsorptive separation of $\mathrm{Kr}-\mathrm{N}_{2}$ mixture. They screened the adsorbents (Ruthven et al. 1984), developed a chromatographic process for the separation (Tezel et al. 1986) and designed a pilot plant for the process (Tezel et al. 1990). PSA processes for separation of trace component (Ruthven and Farooq 1994) such as Argon from air as well as bulk separation were investigated (Hassan et al. 1986, 1987). In a series of papers by Ching and Ruthven, they analyzed a simulated countercurrent adsorption process (Ching and Ruthven 1985a, 1985b, 1986; Ching et al. 1985) and applied it for the separation of glucose and fructose (Ching and Ruthven 1985c). PSA processes for kinetically controlled systems and piston driven processes were also investigated. His second book on Pressure Swing Adsorption Processes, co-authored with Knaebel and Farooq was published at this time.

\subsection{Notable contributions}

Prof. Ruthven was one of the first few scientists to apply the principles of statistical thermodynamics to describe the phenomenon of adsorption occurring in discrete cages interconnected through relatively small windows. He was also instrumental in popularizing the use of chromatographic technique for the measurement of one component and binary adsorption and diffusion in zeolites. He is credited with developing the ZLC technique, a fast and reliable method for studying adsorption and diffusion in zeolites. Prof. Ruthven has made numerous contributions in the area of adsorption column dynamics for isothermal and nonisothermal operation. He has also made significant contributions in the field of pressure swing adsorption processes, countercurrent adsorption columns and simulated moving beds.

\subsection{Awards \& honors}

Prof. Ruthven is a long-time consultant to Exxon Research $\&$ Engineering. In addition, he has consulted with many international companies world wide. He has co-taught an AIChE continuing education course on "Adsorption: Theory \& Practice" for more than thirty times. Prof. Ruthven has supervised 64 masters and doctoral students, and post doctoral fellows in his laboratory. He has held prestigious editorial positions for some of the most prominent chemical engineering journals such as Chemical Engineering Science, Industrial Engineering Chemistry Research, Zeolites, Gas Separation \& Purification and Adsorption. He has been the President of International Adsorption Society and has been a member of the organizing committee for the Fundamentals of Adsorption conferences. As befits his stature as one of the foremost scientists in the field of zeolites science and engineering, Prof. Ruthven has made many invited presentations at professional society meetings of the AIChE, ACS, CSChE, etc. In 1999, he was selected by the Canadian Society of Chemical Engineers to receive century of Achievement award as one of the eminent chemical engineers in Canada. He has been conferred a DSc degree by the Cambridge University in 1988 and was elected a Fellow of the Royal Society of Canada in 1989. He was awarded the Max Planck Research award in 1993 and the Humboldt Foundation award from Germany in 2003.

The list of his contributions to the field will not be complete without mentioning the three books he has authored or co-authored. The first book on the Principles of Adsorption and Adsorption Processes was published in 1984 and quickly became an important reference book in the field. A crude estimate indicates that it has been cited about 2700 times. His book "Diffusion in Zeolites and Other Microporous Solids" co-authored with Prof. Kärger, was published in 1992 and it has been cited more than 1300 times. Finally his book "Pressure Swing Adsorption Processes" was coauthored with Knaebel and Farooq and was published in 1994. It has been cited 335 times.

\subsection{Students and collaborators}

Prof. Ruthven has, of course, an extensive collaboration with Prof. Jörg Kärger. Prof. Ruthven has supervised 18 masters and $26 \mathrm{PhD}$ students along with 20 post doctoral fellows in his laboratory. Some of his students presently occupy faculty positions in many countries. These individuals are listed in Table 1 along with their present positions and the time period they spent at the University of New Brunswick. Some of his students and postdoctoral fellows are shown in Fig. 1.

\subsection{Fifteen most cited papers}

In order to gauge his overall impact on the field of zeolite science and engineering, I looked up his fifteen most cited papers as reported by Web of Science. These are listed in Table 2 along with the number of times each paper has been cited. It is interesting to note that of these fifteen papers, three are in the area of counter-current and simulated counter-current adsorption processes (numbers 1, 9, 13), seven are in the area of sorption and diffusion (numbers 2 , $5,6,8,10,11,12)$ and three are in the area of fixed bed 
Table 1 Prof. Ruthven's students at other academic institutions

\begin{tabular}{lll}
\hline Name & Years at UNB & Present Affiliation \\
\hline S. Brandani & $1994-1995$ & University of Edinburgh, Scotland \\
Z. Xu & $1990-1991$ & University of Shanghai, China \\
H. Yoshida & $1982-1984$ & Osaka Prefecture University, Japan \\
C. Cavalcante & $1990-1993$ & University of Fortrleza, Brazil \\
S. Farooq, C.B. Ching & $1985-1991$ & National University of Singapore \\
M. Eic & $1984-1987$ & University of New Brunswick, Canada \\
F.H. Tezel & $1981-1986$ & University of Ottawa, Canada \\
H. Yucel & $1975-1979$ & Middle East Technical University, Ankara, Turkey \\
K.F. Loughlin & $1968-1971$ & King Fahd University of Petroleum and Minerals, Saudi Arabia \\
T.S. Sridhar & $1966-1969$ & Carleton University, Canada \\
D.B. Shah & $1975-1977$ & Cleveland State University, USA \\
\hline
\end{tabular}

Fig. 1 Prof. Ruthven with some of his former students and post-doctoral fellows

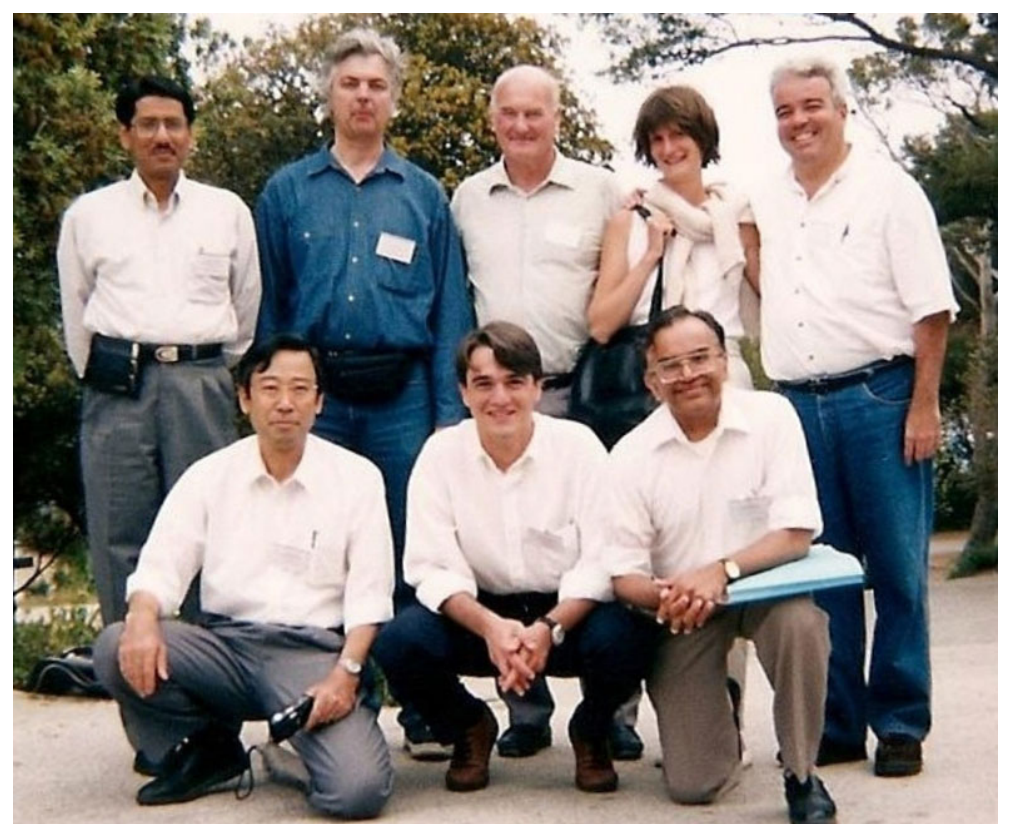

adsorption column behavior $(7,14,15)$. Of these, two papers co-authored with Prof. Kärger $(3,4)$ also make the list. These papers are on the comparison of micropore diffusivities measured by macroscopic methods and those measured by the microscopic methods. This illustrates the wide ranging impact that Prof. Ruthven has had in the areas of zeolites adsorption and diffusion, simulation and modeling of adsorption column behavior, pressure swing processes, and counter-current and simulated moving bed processes.

\section{Prof. Jörg Kärger}

Prof. Kärger was born in the town of Erfurt, about 100 miles from the city of Leipzig where he has spent his entire professional career first as a graduate student and then as a faculty member at the University of Leipzig. He received his $\mathrm{PhD}$ in 1970 and did his habilitation under Prof. Harry Pfeifer in 1978. He stayed with the University rising through the academic ranks (Lecturer, 1982-1989: Professor, 19891994 and Full Professor 1994-2009). As a Full Professor, Prof. Kärger maintained a group of 30-35 persons consisting of full-time researchers, $\mathrm{PhD}$ and diploma students (both German and European) and hosted, in his lab, scholars from Europe, Asia and Americas. His research efforts were well funded by Deutsche Forschungsgemeinschaft (DFG), European Union and industrial companies such as BASF AG. He was always on the lookout for possible collaboration with other scientists for funding and joint research programs. He has an enviable record of getting research funding from a variety of sources. He kept a backbreaking schedule of being in the office by 7:00 am everyday and leaving on most 
Table 2 Fifteen most cited papers of Prof. Ruthven

\begin{tabular}{|c|c|c|c|c|}
\hline & Authors & Title & Journal & Citations \\
\hline 1 & $\begin{array}{l}\text { D.M. Ruthven, } \\
\text { C.B. Ching }\end{array}$ & $\begin{array}{l}\text { Counter-Current and Simulated Counter-Current } \\
\text { Adsorption Separation Processes }\end{array}$ & Chem. Eng. Sci. 44, 1011-1038 (1989) & 291 \\
\hline 2 & $\begin{array}{l}\text { M. Eic, } \\
\text { D.M. Ruthven }\end{array}$ & $\begin{array}{l}\text { New Experimental Technique for Measurement of } \\
\text { Intracrystalline Diffusivity }\end{array}$ & Zeolites 8, 40-45 (1988) & 134 \\
\hline 3 & $\begin{array}{l}\text { J. Kärger, } \\
\text { D.M. Ruthven }\end{array}$ & $\begin{array}{l}\text { On the Comparison between Macroscopic and } \\
\text { NMR Measurements of Intracrystalline Diffusion } \\
\text { in Zeolites }\end{array}$ & Zeolites 9, 267-281 (1989) & 127 \\
\hline 4 & $\begin{array}{l}\text { J. Kärger, } \\
\text { D.M. Ruthven }\end{array}$ & $\begin{array}{l}\text { Diffusion in Zeolites: Comparison of Sorption } \\
\text { and NMR Diffusivities }\end{array}$ & $\begin{array}{l}\text { J. Chem. Soc. Faraday Trans. I 77, 1485-1496 } \\
\text { (1981) }\end{array}$ & 120 \\
\hline 5 & $\begin{array}{l}\text { D.M. Ruthven and } \\
\text { R.I. Derrah }\end{array}$ & $\begin{array}{l}\text { Diffusion of Monatomic and Diatomic Gases in } \\
4 \mathrm{~A} \text { and } 5 \mathrm{~A} \text { Zeolites }\end{array}$ & $\begin{array}{l}\text { J.Chem.Soc. Faraday Trans. I 71, 2031-2044 } \\
\text { (1975) }\end{array}$ & 90 \\
\hline 6 & $\begin{array}{l}\text { D.M. Ruthven, } \\
\text { R.I. Derrah }\end{array}$ & Transition State Theory of Zeolitic Diffusion & $\begin{array}{l}\text { J. Chem. Soc. Faraday Trans I 68, 2332-2342 } \\
\text { (1972) }\end{array}$ & 89 \\
\hline 7 & $\begin{array}{l}\text { N.S. Raghavan, } \\
\text { D.M. Ruthven }\end{array}$ & $\begin{array}{l}\text { Numerical Simulation of a Fixed Bed Adsorption } \\
\text { Column by the Method of Orthogonal Collocation }\end{array}$ & AIChE J. 29, (6), 922-925 (1983) & 80 \\
\hline 8 & D.M. Ruthven & $\begin{array}{l}\text { Sorption of } \mathrm{O}_{2}, \mathrm{~N}_{2}, \mathrm{CO}, \mathrm{CH}_{4} \text { and Binary } \\
\text { Mixtures in } 5 \mathrm{~A} \text { Zeolite }\end{array}$ & AIChE J. 22, 753-759 (1976) & 80 \\
\hline 9 & $\begin{array}{l}\text { C.B. Ching, } \\
\text { D.M. Ruthven }\end{array}$ & $\begin{array}{l}\text { Experimental Study of a Simulated } \\
\text { Counter-Current Adsorption System, Part I: } \\
\text { Isothermal, Steady State Operation }\end{array}$ & Chem. Eng. Sci. 40, 877-886 (1985) & 78 \\
\hline 10 & $\begin{array}{l}\text { D.M. Ruthven, } \\
\text { K.F. Loughlin }\end{array}$ & $\begin{array}{l}\text { The Effect of Crystal Shape and Size Distribution } \\
\text { on Diffusion Measurements in Molecular Sieves }\end{array}$ & Chem. Eng. Sci. 26, 577-584 (1971) & 78 \\
\hline 11 & $\begin{array}{l}\text { D.B. Shah, } \\
\text { D.M. Ruthven }\end{array}$ & $\begin{array}{l}\text { Measurement of Zeolitic Diffusivities and } \\
\text { Equilibrium Isotherms by Chromatography }\end{array}$ & AIChE J. 23, 804-809 (1977) & 74 \\
\hline 12 & $\begin{array}{l}\text { D.M. Ruthven } \\
\text { K.F. Loughlin, } \\
\text { K.A. Holborow }\end{array}$ & $\begin{array}{l}\text { Multicomponent Sorption Equilibrium in } \\
\text { Molecular Sieves }\end{array}$ & Chem. Eng. Sci. 28, 701-709 (1973) & 73 \\
\hline 13 & $\begin{array}{l}\text { C.B. Ching, } \\
\text { D.M. Ruthven }\end{array}$ & $\begin{array}{l}\text { Experimental Study of a Simulated } \\
\text { Counter-Current Adsorption System, Part II: } \\
\text { Transient Response }\end{array}$ & Chem. Eng. Sci. 40, 887-891 (1985) & 72 \\
\hline 14 & $\begin{array}{l}\text { D.M. Ruthven, } \\
\text { Lap-Keung Lee }\end{array}$ & $\begin{array}{l}\text { Non-Isothermal Sorption Kinetics: System with } \\
\text { Bed Diffusion Control }\end{array}$ & AIChE J. 27, 654-663 (1981) & 72 \\
\hline 15 & $\begin{array}{l}\text { D.M. Ruthven, } \\
\text { L.K. Lee, H. Yucel }\end{array}$ & $\begin{array}{l}\text { Kinetics of Non-Isothermal Sorption in Molecular } \\
\text { Sieves }\end{array}$ & AIChE J. 26, 16-23 (1980) & 70 \\
\hline
\end{tabular}

All citation numbers are as of July 2009

nights after 6:00 pm. Many a weekends, he would be there in the office as well. He has succeeded in his academic career under two different political systems in pre and post unification of Germany. This is a tribute to his adaptability and perseverance.

\subsection{His contributions}

Over an academic career spanning more than 40 years, Jörg Kärger has made many valuable contributions in the field of zeolite science. He, along with Prof. Pfeifer, and their coworkers, is most noted for developing, adapting and popularizing the use of Pulsed Field Gradient NMR (PFG NMR) method to study the diffusion of substances in different types of zeolite pore geometries. They adapted the conventional PFG NMR technique by using large magnetic field gradients to measure much smaller values of micropore diffusivities. Prof. Kärger was the first researcher to introduce the propagator representation of molecular transport to study the selfdiffusion of hydrocarbons in zeolites. His group modified the PFG NMR with fast tracer desorption to measure much slower diffusion.

Prof. Kärger's initial work emphasized the study of relatively faster diffusion processes of small molecules such as water in large pore zeolites such as 13X (Kärger 1971), NaY (Kärger et al. 1973) and alkanes in NaX (Kärger and Walter 1974; Kärger et al. 1980) with PFG NMR. He then moved into studying slower diffusion and self diffusion processes of lower carbon number alkanes in 4A and 5A zeolites (Kärger and Caro 1975; Caro et al. 1976). Thereafter, he started studying much slower transport processes with diffusion of larger molecules such as n-butane to n-octane (Kärger et 
al. 1978a, 1978b, 1978c, 1980) and benzene, toluene and xylenes in NaX (Kärger et al. 1978a, 1978b, 1978c; Germanus et al. 1985). In a series of papers co-authored with Bülow, Kocirik and Caro, for example (Kärger and Bülow 1975; Kärger et al. 1976, 1978a, 1978b, 1978c; Kärger and Caro 1977), they analyzed adsorption kinetics using both uptake and NMR measurements for single component and binary systems, and provided an early evidence of the existence of external barriers on zeolite crystals (Bülow et al. 1980). In mid-eighties, Prof. Kärger started studying transport processes in pentasil zeolites, for example (Kärger et al. 1982; Caro et al. 1985, 1986).

Prof. Kärger has investigated transport properties of a variety of molecules in different types of porous materials. These include crystalline microporous adsorbents: different zeolites such as LTA, MFI, Faujasite, natural chabazite, AFI, $\mathrm{ALPO}_{4}{ }^{-5}$ and ferrierite. He and his co-workers have also investigated VPI-5 (Kärger et al. 1995), mesoporous materials (Dvoyashkin et al. 2007) such as porous silicon (Naumov et al. 2008), porous glass (Heyer et al. 1982) and metalorganic-frameworks (Stallmach et al. 2006; Chmelik et al. 2009) and conventional adsorbents such as activated carbon (Heink et al. 1993) and silica gel (Roethe et al. 1986). They have also studied diffusion in materials such as cement (Nestle et al. 2004) and polymer melts (Appel et al. 1994). Majority of Prof. Kärger's work until about mid-nineties used NMR methods for characterizing the pore structures of different types of zeolites. Over the last fifteen years or so, he has also extensively worked on improving and developing two mesoscopic methods: Infra-Red (IR) Spectroscopy and Interference Microscopy (IFM) (Karge and Kärger 2008). These two methods study the process of adsorption and diffusion as applied to a single crystal. The methods allow us to monitor how internal sorbate concentration profiles change with time. For perhaps the first time, one can monitor the evolution of concentration profiles and use these to determine local micropore diffusivities.

Prof. Kärger has investigated a wide range of topics in zeolite diffusion such as dependence of diffusion on adsorbed phase concentration (Gutsche et al. 1985; Pfeifer et al. 1985), diffusion in binary and ternary mixtures (Förste et al. 1987; Fleischer et al. 1997), effect of pretreatment conditions on diffusion (Kärger et al. 1981), etc. He was probably the first one to report on the diffusion anisotropy (Zibrowius et al. 1988). He has also contributed significantly on single file diffusion (Kärger 1992; Kärger et al. 1982; Hahn et al. 1996). Over the last ten years of his career, his group also started working on the molecular dynamics to predict diffusivities and understand the diffusion process. With the help of the two mesoscopic techniques (IR and IFM), he and his coworkers measured and analyzed the evolution of concentration profiles to determine local diffusivities (Kärger et al. 2006; Heinke et al. 2007). They also were able to identify crystal morphology (Tzoulaki et al. 2008a), surface permeabilities and hence the presence of surface barriers (Tzoulaki et al. 2008b). These fundamental contributions have been made in the last ten years or so and with time, these techniques will find increasing use in the research community in probing host-guest properties.

\subsection{Fifteen most cited papers of Prof. Kärger}

Prof. Kärger's fifteen most cited papers are listed in Table 3. Since he is most noted for his enormous contributions in exploring Nuclear Magnetic Resonance technique for investigating the transport of molecules in porous structures, it is not surprising, therefore, to find that ten of the fifteen papers listed in the table are in this area. He has three other papers in the list that deal with the topic of single file diffusion. His joint papers with Prof. Ruthven on comparing the micropore diffusivities measured by NMR and those measured by sorption experiments also make the list.

A closer examination of the list also provides a clue about the extent of collaboration he has always maintained with other scientists. His collaboration with Prof. Caro has continued even after Prof. Caro completed his habilitation under Prof. Kärger. Two papers co-authored by them occupy positions 4 and 5 in the list. Three other collaborative works also make the list (Prof. Weitkamp of University of Stuttgart at 9, Dr. Jobic of CNRS, France at 14 and Dr. Bülow at 15).

\subsection{His notable "pupils" and collaborators}

Prior to the reunification of Germany in 1989, Prof. Kärger worked with some of the most well known scientists in the iron-curtain countries. He had a wide-ranging collaboration with 3 groups of scientists in eastern countries. His collaborative work with the Russian Professor S.P. Zhdanov from Leningrad (now St. Petersburg) produced 11 joint publications during the period of 1972-1993. Two of these papers are at \#4 and \#12 in the fifteen most cited articles. He also collaborated extensively with the Czech couple (Dr. M. Kocirik and his wife A. Zikanova) and published 9 joint papers with them in the period 1978-1987. His collaboration with Prof. M.M. Dubinin from Moscow produced 6 joint papers. After unification of Germany in 1989, Jörg expanded his collaboration significantly with scientists in West Germany (Profs. H.G. Karge, Weitkamp, Caro), Greece (Prof. Theodorou), Netherlands (Profs. Kaptein, Krishna, van Baten), the United Kingdom (Profs. Brandani, Rees), France (Dr. Jobic) and the USA (Profs. Monson, Aurabach). A list of his notable collaborators is provided in Table 4.

\subsection{Awards and honors}

Prof. Kärger has been the recipient of several honors and awards. The German Physics Society, in 1978, honored him 
Table 3 Fifteen most cited papers of Prof. Kärger

\begin{tabular}{|c|c|c|c|c|}
\hline & Authors & Title & Journal & Citations \\
\hline 1 & J. Kärger, H. Pfeifer & $\begin{array}{l}\text { NMR Self-Diffusion Studies in Zeolite Science } \\
\text { and Technology }\end{array}$ & Zeolites 7, 90-107 (1987) & 215 \\
\hline 2 & J. Kärger, W. Heink & $\begin{array}{l}\text { The Propagator Representation of Molecular } \\
\text { Transport in Microporous Crystallites }\end{array}$ & J. Magn. Res. 51, 1-7 (1983) & 190 \\
\hline 3 & K. Hahn, J. Kärger, V. Kukla & Single-File Diffusion Observation & $\begin{array}{l}\text { Phys. Rev. Lett. 76, 2762-2765 } \\
\text { (1996) }\end{array}$ & 159 \\
\hline 4 & $\begin{array}{l}\text { J. Caro. M. Bülow, } \\
\text { W. Schirmer, J. Kärger, } \\
\text { W. Heink, H. Pfeifer, } \\
\text { S.P. Zhdanov }\end{array}$ & $\begin{array}{l}\text { Microdynamics of Methane, Ethane and Propane } \\
\text { in ZSM-5 Type Zeolites }\end{array}$ & $\begin{array}{l}\text { J. Chem. Soc. Faraday Trans. I } \\
\text { 81, 2541-2550 (1985) }\end{array}$ & 155 \\
\hline 5 & J. Kärger, J. Caro & $\begin{array}{l}\text { Interpretation and Correlation of Zeolitic } \\
\text { Diffusivities Obtained from Nuclear Magnetic } \\
\text { Resonance and Sorption Experiments }\end{array}$ & $\begin{array}{l}\text { J. Chem. Soc. Faraday Trans. I } \\
\text { 73, 1363-1376 (1977) }\end{array}$ & 150 \\
\hline 6 & $\begin{array}{l}\text { V. Kukla, J. Kornatowski, } \\
\text { D. Demuth, I. Girnus, } \\
\text { H. Pfeifer, L.V.C. Rees, } \\
\text { S. Schunk, K.K. Unger, } \\
\text { J. Kärger }\end{array}$ & $\begin{array}{l}\text { NMR Studies of Single-File Diffusion in } \\
\text { Unidimensional Channel Zeolites }\end{array}$ & Science 272, 702-704 (1996) & 144 \\
\hline 7 & J. Kärger, D.M.Ruthven & $\begin{array}{l}\text { On the Comparison between Macroscopic and } \\
\text { NMR Measurements of Intracrystalline Diffusion } \\
\text { in Zeolites }\end{array}$ & Zeolites 9, 267-281 (1989) & 127 \\
\hline 8 & J. Kärger, D.M. Ruthven & Diffusion in Zeolites & $\begin{array}{l}\text { J. Chem. Soc. Faraday Trans. I } \\
\text { 77, 1485-1496 (1981) }\end{array}$ & 120 \\
\hline 9 & $\begin{array}{l}\text { J. Kärger, M. Petzold, } \\
\text { H. Pfeifer, S. Ernst, } \\
\text { J. Weitkamp }\end{array}$ & Single-File Diffusion and Reaction in Zeolites & J. Catal. 136, 283-299 (1992). & 117 \\
\hline 10 & $\begin{array}{l}\text { J. Kärger, H. Pfeifer, } \\
\text { M. Rauscher, A. Walter }\end{array}$ & Self-Diffusion of n-Paraffins in NaX Zeolite & $\begin{array}{l}\text { J. Chem. Soc. Faraday Trans. I } \\
\text { 76, 717-737 (1980) }\end{array}$ & 116 \\
\hline 11 & R.Q. Snurr, J. Kärger & $\begin{array}{l}\text { Molecular Simulations and NMR Measurements } \\
\text { of Binary Diffusion in Zeolites }\end{array}$ & $\begin{array}{l}\text { J. Phys. Chem. B 101, } \\
\text { 6469-6473 (1997) }\end{array}$ & 96 \\
\hline 12 & $\begin{array}{l}\text { A. Germanus, J. Kärger, } \\
\text { H. Pfeifer, N.N. Samulevich, } \\
\text { S.P. Zhdanov }\end{array}$ & $\begin{array}{l}\text { Intracrystalline Self-Diffusion of Benzene, } \\
\text { Toluene and Xylene Isomeres in Zeolites } \mathrm{NaX}\end{array}$ & Zeolites 5, 91-95 (1985) & 95 \\
\hline 13 & $\begin{array}{l}\text { W. Heink, J. Kärger, } \\
\text { H. Pfeifer, K.P. Datema, } \\
\text { A.K. Nowak }\end{array}$ & $\begin{array}{l}\text { High-Temperature Pulsed Field Gradient Nuclear } \\
\text { Magnetic Resonance Self-Diffusion } \\
\text { Measurements of n-Alkanes in MFI-Type Zeolites }\end{array}$ & $\begin{array}{l}\text { J. Chem. Soc. Faraday Trans. I, } \\
\mathbf{8 8 ,} \text {, 3505-3509 (1992) }\end{array}$ & 86 \\
\hline 14 & H. Jobic, J. Kärger, M. Bée & $\begin{array}{l}\text { Simultaneous Measurement of Self- and } \\
\text { Transport Diffusivities in Zeolites }\end{array}$ & $\begin{array}{l}\text { Phys. Rev. Lett. 82, 4260-4263 } \\
\text { (1999) }\end{array}$ & 81 \\
\hline 15 & J. Kärger, M. Bülow & $\begin{array}{l}\text { Theoretical prediction of uptake behaviour in } \\
\text { adsorption kinetics of binary gas mixtures using } \\
\text { irreversible thermodynamics }\end{array}$ & $\begin{array}{l}\text { Chem. Eng. Sci. 30, 893-896 } \\
\text { (1975) }\end{array}$ & 76 \\
\hline
\end{tabular}

All citation numbers are as of July 2009.

with Gustav-Hertz award. The German Academy of Sciences, in 1980, awarded him the Leibnitz Medal. From the International Zeolite Association (IZA), Prof. Kärger received the Donald Breck award in 1986. The award is presented at each IZA conference "to an individual or group for significant contribution to molecular sieve science and technology achieved since the last conference". Their group was cited for their NMR investigations of acidity and transport in zeolites. In 1993, he received Max Planck Research award from the Humboldt Foundation and the Max Planck Soci- ety. The award is presented to a scientist working in Germany and to a scientist working abroad, who have both already gained international recognition and who are expected to continue to deliver an outstanding performance in the field of international scientific cooperation. Profs. Kärger and Ruthven jointly won this award in 1993. As befits his standing in the profession, he has been an editor of many journals including Adsorption, Zeolites, and Microporous and Mesoporous Materials. He has also been an editor and/or co-editor of a number of books. 
Table 4 Prof. Kärger's Students and Collaborators and their present affiliations

\begin{tabular}{lll}
\hline Prof. J. Caro & PhD \& Habilitation & Hannover University \\
Dr. Frank Stallmach & Habilitation & University of Leipzig \\
Dr. S. Vasenkov & Habilitation & University of Florida \\
Dr. S. Brandani & Collaborator & University of Edinburgh \\
Dr. H. Jobic & Collaborator & CNRS, France \\
Profs. R. Krishna, & Collaborator & University of Amsterdam \\
F. Kaptein & & Delft Institute of Technology \\
Prof. D. Theodorou & Collaborator & National Technical University of Athens, Greece \\
Prof. Ruthven & Collaborator & University of Maine \\
Profs. Monson, Aurabach & Collaborators & University of Massachusetts \\
Prof. Randy Snurr & Collaborator & Northwestern University \\
Prof. H.G. Karge & Collaborator & Max Planck Society, Fritz Haber Institute \\
Prof. Jens Weitkamp & Collaborator & University of Stuttgart \\
Prof. Yashonath & Collaborator & Indian Institute of Science \\
\hline
\end{tabular}

\section{Common traits of both scientists}

Since both these individuals have attained such prominent positions in their professional careers, it is tempting to look for some common traits that run through these two individuals. First and foremost, they are open to new ideas. This is indicated by the fact that when discrepancies were discovered between macroscopically and microscopically determined micropore diffusivities for the same adsorbentadsorbate systems, rather than dismissing each other's results, they kept open minds and worked together to find reasons for such discrepancies. Secondly, both are excited by new findings and possess passion for science. Because they possess broad knowledge base, they are able to rationalize apparently disparate findings based on unifying scientific principles. Both have superb organizational skills, ability to focus on diverse projects and complete them. Both researchers are excellent writers. They have to be in order to publish over 700 papers and several books between them. Both love nature and have a passion for hiking in the mountains or in metro parks. Whenever these two get together, be it in Leipzig or in Maine or any other conference location, they are always on the lookout for opportunities to go hiking on mountains or walk the trails in metro parks. Both love good food, beer and wine.

Both Profs. Ruthven and Kärger have strong family ties. Pat Ruthven has accompanied Doug Ruthven to numerous conferences and most of us who attend adsorption conferences regularly have had occasions to enjoy her company while hiking or drinking wine and beer or enjoying good food. Birge Kärger, on the other hand, does not travel as frequently with Prof. Kärger. But, those of us who have met her know her kind hearted nature, her passion for outdoor activities and being a gracious host at their home in Leipzig on numerous occasions. Both Kärgers and Ruthvens are close-knit families and their success in professional careers is, in no small measures, due to their strong family ties. Most of all, both Doug and Jörg are better human beings than they are scientists. They are both humble and are easily approachable. I have personally seen Doug talk at length to new researchers (graduate students and/or new faculty or engineers working in industry) about their research problems and giving them advice. I have seen Jörg spend hours with his new graduate students nurturing and indoctrinating them, listening to their concerns and questions and patiently answering them.

Both have passion for teaching and learning. Doug enjoys teaching both undergraduate and graduate chemical engineering classes. Jörg is known for his passion for lecturing in front of an audience whether it is a presentation at a conference or a seminar or in front his undergraduate or graduate students at the University of Leipzig. He has the ability to talk to people at their own levels: be they at the kindergarten level or ordinary folks who know very little about mathematics and science. His lectures deal with principles, reallife examples with which to explain them and are devoid of complicated mathematics. In 2005, he presented a lecture on physics of the bicycle to an audience of over 500 nontechnical people. He provided bicycle bells to each person and orchestrated playing of German Folk songs and hymns by playing the bicycle bells. This resulted in an entry into the Guinness Book of World Records.

\section{Final observations}

As both these extraordinary scientists approach retirement, on behalf of the countless researchers in the field of zeolite science and engineering, I take this opportunity to wish them nothing but the best in the coming years. To honor 
Fig. 2 Academic tree for Prof. Doug Ruthven showing his doctoral and post-doctoral fellows

Fig. 3 Academic tree for Prof. Jörg Kärger showing his doctoral and habilitation students
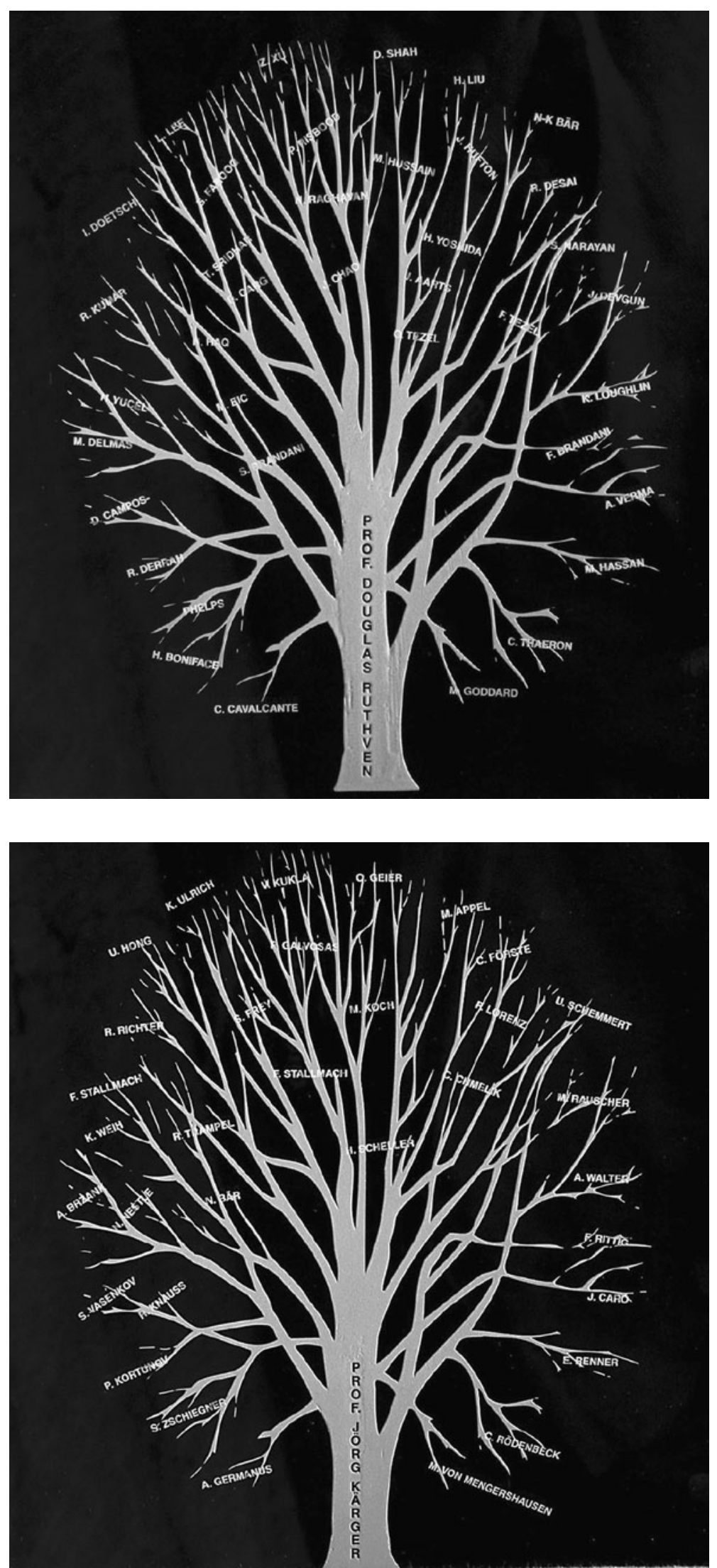
their achievements, a special session was organized at the 58th Canadian Chemical Engineering Conference held in Ottawa, Canada, in October 2008 and they were presented plaques depicting their academic trees with the names of their doctoral and postdoctoral students engraved in glass. These plaques are shown in Figs. 2 and 3.

\section{References}

\section{Prof. Ruthven's Papers}

Boniface, H.A., Ruthven, D.M.: Use of higher moments to extract transport data from chromatographic adsorption experiments. Chem. Eng. Sci. 40, 2053-2061 (1985)

Boulicaut, L., Brandani, S., Ruthven, D.M.: Liquid phase sorption and diffusion of branched and cyclic hydrocarbons in silicalite. Microporous Mater. 25, 81-93 (1998)

Brandani, S., Ruthven, D.M.: Analysis of ZLC desorption curves for liquid systems. Chem. Eng. Sci. 50, 2055-2059 (1995)

Brandani, F., Ruthven, D.M.: Measurement of adsorption equilibrium by the zero length column (ZLC) technique, part 2: binary systems. Ind. Eng. Chem. Res. 42, 1462-1469 (2003)

Brandani, S., Hufton, J., Ruthven, D.M.: Self diffusion of propane and propylene in $5 \mathrm{~A}$ and $13 \mathrm{X}$ zeolite crystals, studied by tracer ZLC. Zeolites 15, 624-631 (1995)

Brandani, S., Cavalcante, C., Guimaraes, A., Ruthven, D.M.: Heat effects in ZLC experiments. Adsorption 4, 275-285 (1998)

Brandani, S., Jama, M.A., Ruthven, D.M.: ZLC measurements under non-linear conditions. Chem. Eng. Sci. 55, 1205-1212 (2000a)

Brandani, S., Jama, M.A., Ruthven, D.M.: Diffusion, self diffusion and counter-diffusion of benzene and p-xylene in silicalite. Microporous Mesoporous Mater. 35, 283-300 (2000b)

Brandani, F., Ruthven, D.M., Coe, C.G.: Measurement of adsorption equilibrium by the zero length column (ZLC) technique, part 1: single component systems. Ind. Eng. Chem. Res. 42, 1451-1461 (2003)

Ching, C.B., Ruthven, D.M.: Experimental study of a simulated counter-current adsorption system, part I: isothermal, steady state operation. Chem. Eng. Sci. 40, 877-886 (1985a)

Ching, C.B., Ruthven, D.M.: Experimental study of a simulated counter-current adsorption system, part II: transient response. Chem. Eng. Sci. 40, 887-891 (1985b)

Ching, C.B., Ruthven, D.M.: Separation of fructose from glucose by simulated counter-current adsorption. AIChE Symp. Ser. 81(242), $1-8(1985 \mathrm{c})$

Ching, C.B., Ruthven, D.M.: Experimental study of a simulated counter-current adsorption system, part IV: nonisothermal operation. Chem. Eng. Sci. 41, 3063-3071 (1986)

Ching, C.B., Ruthven, D.M., Hidajat, K.: Experimental study of a simulated counter-current adsorption system, part III: sorbex operation. Chem. Eng. Sci. 40, 1411-1417 (1985)

Eic, M., Ruthven, D.M.: New experimental technique for measurement of intracrystalline diffusivity. Zeolites 8, 40-45 (1988)

Eic, M., Ruthven, D.M.: Intracrystalline diffusion of linear paraffins and benzene in silicalite studied by the ZLC method. In: Jacobs, P.A., van Santen, R.A. (eds.) Proc. 8th International Zeolite Conf., pp. 897-905. Elsevier, Amsterdam (1989)

Farooq, S., Hassan, M.M., Ruthven, D.M.: Heat effects in pressure swing adsorption systems. Chem. Eng. Sci. 43, 1011-1031 (1988)

Farooq, S., Ruthven, D.M., Boniface, H.A.: Numerical simulation of a PSA oxygen unit. Chem. Eng. Sci. 44, 2809-2816 (1989)
Farooq, S., Ruthven, D.M.: Dynamics of kinetically controlled binary adsorption in a fixed bed. AIChE J. 37, 299-301 (1991)

Garg, D.R., Ruthven, D.M.: On fixed bed sorption of gases with nonlinear equilibria. AIChE J. 19, 852-54 (1973)

Garg, D.R., Ruthven, D.M.: Performance of molecular sieve adsorption columns: systems with macropore diffusion control. Chem. Eng. Sci. 29, 1961-1967 (1974a)

Garg, D.R., Ruthven, D.M.: Performance of molecular sieve adsorption columns: systems with micropore diffusion control. Chem. Eng. Sci. 29, 571-581 (1974b)

Garg, D.R., Ruthven, D.M.: Performance of molecular sieve adsorption columns: combined effects of mass transfer and longitudinal diffusion. Chem. Eng. Sci. 30, 1192-1196 (1975)

Haq, N., Ruthven, D.M.: Chromatographic study of sorption and diffusion in 4A zeolite. J. Colloid Interface Sci. 112, 154-163 (1986)

Hassan, M.M., Raghavan, N.S., Ruthven, D.M., Boniface, H.A.: Pressure swing adsorption, part II: experimental study of a linear, isothermal trace component system. AIChE J. 31, 2008-2016 (1985)

Hassan, M.M., Raghavan, N.S., Ruthven, D.M.: Air separation by pressure swing adsorption on a carbon molecular sieve. Chem. Eng. Sci. 41, 1333-1343 (1986)

Hassan, M.M., Raghavan, N.S., Ruthven, D.M.: Numerical simulation of a psa air separation system - comparative study of finite difference and collocation methods. Can. J. Chem. Eng. 65, 512-516 (1987)

Jiang, M., Eic, M., Ruthven, D.M.: Transport properties of ethane, butane and their binary mixtures studied by ZLC. In: Kaneko, K. (ed.) 7th Int. Adsorption Conf. Proceedings, pp. 732-739. IAS (2002)

Raghavan, N.S., Ruthven, D.M.: Pressure swing adsorption, part III: numerical simulation of a kinetically controlled bulk gas separation. AIChE J. 31, 2017-2025 (1985)

Raghavan, N.S., Hassan, M.M., Ruthven, D.M.: Pressure swing adsorption, part I: numerical simulation of an isothermal trace component system. AIChE J. 31, 385-392 (1985)

Risbood, P.A., Ruthven, D.M.: Bromine adsorbed on molecular sieves: a reagent for selective bromination. J. Am. Chem. Soc. 100, 4919 4921 (1978)

Risbood, P.A., Ruthven, D.M.: Selective reduction of aldehydes in presence of ketones. J. Org. Chem. 44, 3969-3970 (1979)

Ruthven, D.M.: A simple theoretical isotherm for zeolites. Nat. Phys. Sci. 232(29), 70-71 (1971)

Ruthven, D.M.: Simple theoretical isotherm for zeolites-further comments. Zeolites 2(4), 242-243 (1982)

Ruthven, D.M., Eic, M., Richard, E.: Diffusion of $\mathrm{C}_{8}$ aromatic hydrocarbons in silicalite. Zeolites 11, 647-653 (1991)

Ruthven, D.M., Farooq, S.: Concentration of a trace component by pressure swing adsorption. Chem. Eng. Sci. 49, 51-60 (1994)

Ruthven, D.M., Kumar, R.: A chromatographic study of diffusion of $\mathrm{N}_{2}, \mathrm{CH}_{4}$ and binary $\mathrm{CH}_{4}-\mathrm{N}_{2}$ mixtures in $4 \mathrm{~A}$ molecular sieve. Can. J. Chem. Eng. 57, 342-348 (1979)

Ruthven, D.M., Lee, L.-K.: Nonisothermal sorption kinetics: system with bed diffusion control. AIChE J. 27, 654-663 (1981)

Ruthven, D.M., Garg, D.R., Crawford, R.M.: Performance of molecular sieve adsorption column: nonisothermal systems. Chem. Eng. Sci. 30, 803-810 (1975)

Ruthven, D.M., Tezel, F.H., Devgun, J.S., Sridhar, T.S.: Adsorptive separation of $\mathrm{Kr}$ from $\mathrm{N}_{2}$, part I: adsorbent screening studies. Can. J. Chem. Eng. 62, 526-534 (1984)

Ruthven, D.M., Stapleton, P., Dahlke, R.: Application of the ZLC method to measurement of intracrystalline diffusion in liquidzeolite systems. In: von Ballmoos, R., Higgins, J.B. et al. (eds.) Proc. 9th Int. Zeolite Conf., vol 2, pp. 99-103 (1993)

Shah, D.B., Ruthven, D.M.: Measurement of zeolitic diffusivities and equilibrium isotherms by chromatography. AIChE J. 23, 804-809 (1977) 
Tezel, F.H., Ruthven, D.M., Sridhar, T.S.: Development of a chromatographic process for $\mathrm{Kr}-\mathrm{N}_{2}$ separation. In: King, C.J. (ed.) Chemical Separation, vol. 2, pp. 339-349. Litarvan Literature, Denver (1986)

Tezel, F.H., Ruthven, D.M., Boniface, H.A., Sridhar, T.S.: Adsorption separation of $\mathrm{Kr}$ from $\mathrm{N}_{2}$, II: development of a pilot unit. Can. J. Chem. Eng. 68, 268-277 (1990)

Yoshida, H., Kataoka, T., Ruthven, D.M.: Analytical solution for the breakthrough curve for rectangular isotherm systems. Chem. Eng. Sci. 39, 1489-1497 (1984)

\section{Prof. Ruthven's Books}

Kärger, J., Ruthven, D.M.: Diffusion in Zeolites and Other Microporous Solids. Wiley, New York (1992)

Ruthven, D.M.: Principles of Adsorption and Adsorption Processes. Wiley, New York (1983)

Ruthven, D.M., Farooq, S., Knaebel, K.: Pressure Swing Adsorption. VCH, New York (1993)

\section{Prof. Kärger's Papers}

Appel, M., Fleischer, G., Kärger, J., Fujara, F., Chang, I.: Anomalous segmental diffusion in polymer melts. Macromolecules 27, 42744277 (1994)

Bülow, M., Struve, P., Finger, G., Redszus, C., Ehrhardt, K., Schirmer, W., Kärger, J.: Sorption kinetics of $n$-hexane on MgA zeolites of different crystal size. J. Chem. Soc. Faraday Trans. I 76, 597-615 (1980)

Caro, J., Kärger, J., Finger, G., Pfeifer, H., Schöllner, R.: Zur Selbstdiffusion von Methan und Ethan in A-Zeolithen. Z. Phys. Chem., Leipz. 257, 903-912 (1976)

Caro, J., Bülow, M., Schirmer, W., Kärger, J., Heink, W., Pfeifer, H., Zhdanov, S.P.: Microdynamics of methane, ethane and propane in ZSM-5 type zeolites. J. Chem. Soc. Faraday Trans. I 81, 25412550 (1985)

Caro, J., Hocevar, S., Kärger, J., Riekert, L.: Intracrystalline selfdiffusion of $\mathrm{H}_{2} \mathrm{O}$ and $\mathrm{CH}_{4}$ in ZSM-5 zeolites. Zeolites 6, 213-216 (1986)

Chmelik, C., Kärger, J., Wiebcke, M., Caro, J., van Baten, J.M., Krishna, R.: Adsorption and diffusion of alkanes in CuBTC crystals investigated using infra-red microscopy and molecular simulations. Microporous Mesoporous Mater. 117, 22-32 (2009)

Dvoyashkin, M., Valiullin, R., Kärger, J.: Supercritical fluids in mesopores - new insight using NMR. Adsorption 13, 197-200 (2007)

Fleischer, G., Grätz, K., Kärger, J., Mayer, H.W., Quitzsch, K.: Pulsed field gradient $\mathrm{nmr}$ self-diffusion study in distinct phases of the ternary system water $n$-heptane/igepal CA-520. J. Colloid Interface Sci. 190, 9-16 (1997)

Förste, Ch., Germanus, A., Kärger, J., Pfeifer, H., Caro, J., Pilz, W., Zikanova, A.: Molecular mobility of methane adsorbed on ZSM5 containing co-adsorbed benzene, and the location of the benzene molecules. J. Chem. Soc. Faraday Trans. I 83, 2301-2309 (1987)

Germanus, A., Kärger, J., Pfeifer, H., Samulevich, N.N., Zhdanov, S.P.: Intracrystalline self-diffusion of benzene, toluene and xylene isomeres in zeolites NaX. Zeolites 5, 91-95 (1985)

Gutsche, R., Fiedler, K., Kärger, J.: Concentration dependence of Fickian diffusivity in solutions and sorption systems. J. Chem. Soc. Faraday Trans. I 81, 3103-3108 (1985)

Hahn, K., Kärger, J., Kukla, V.: Single-file diffusion observation. Phys. Rev. Lett. 76, 2762-2765 (1996)
Heink, W., Kärger, J., Pfeifer, H., Vartapetian, R.S., Voploshchuk, A.M.: PFG NMR study of multicomponent self-diffusion on active carbon. Carbon 31, 1083-1087 (1993)

Heinke, L., Chmelik, C., Kortunov, P., Ruthven, D.M., Shah, D.B., Vasenkov, S., Kärger, J.: Application of interference microscopy and IR microscopy for characterizing and investigating mass transport in nanoporous materials. Chem. Eng. Technol. 30, 995 $1002(2007)$

Heyer, W., Janowski, F., Kärger, J., Lenzner, J., Pfeifer, H., Wolf, F.: NMR Untersuchungen zur Desorptionskinetik von OlefinParaffin-Gemischen an porösen Gläsern. Z. Chem. 22, 152-153 (1982)

Karge, H.G., Kärger, J.: Application of IR spectroscopy, IR microscopy, and optical interference microscopy to diffusion in zeolites. In: Karge, H.G., Weitkamp, J. (eds.) Adsorption and Diffusion. Molecular Sieves, vol. 7, pp. 135-206. Springer, Berlin (2008)

Kärger, J.: Diffusionsuntersuchung von Wasser an 13X- sowie 4A- und 5A-Zeolithen mit Hilfe der Methode der gepulsten Feldgradienten. Z. Phys. Chem., Leipz. 248, 27 (1971)

Kärger, J.: A straightforward derivation of the long-time limit of the mean square displacement in single-file systems. Phys. Rev. A 45, 4173-4174 (1992)

Kärger, J., Bülow, M.: Theoretical prediction of uptake behaviour in adsorption kinetics of binary gas mixtures using irreversible thermodynamics. Chem. Eng. Sci. 30, 893-896 (1975)

Kärger, J., Caro, J.: Intracrystalline self-diffusion of methane in 5A molecular sieves. J. Colloid Interface Sci. 52, 623-625 (1975)

Kärger, J., Caro, J.: Interpretation and correlation of zeolitic diffusivities obtained from nuclear magnetic resonance and sorption experiments. J. Chem. Soc. Faraday Trans. I 73, 1363-1376 (1977)

Kärger, J., Walter, A.: Messung der Selbstdiffusin von Alkanen an NaX-Zeolithen mit Hilfe der Feldgradientenimpulstechnik der kernmagnetischen Resonanz. Z. Phys. Chem., Leipz. 255, 142-148 (1974)

Kärger, J., Pfeifer, H., Riedel, E., Winkler, H.: Self-diffusion measurements of water adsorbed in NaY zeolites by means of NMR pulsed field gradient techniques. J. Colloid Interface Sci. 44, 187-188 (1973)

Kärger, J., Bülow, M., van Phat, N.: Zur Kinetik der Gasphasenadsorption von $n$-Hexan an NaX-Zeolith. II. Vergleich der Sorptions- und NMR-Selbstdiffusionsmessungen an Zeolithen von unterschiedlicher Kristallgröße. Z. Phys. Chem., Leipz. 257, 1217-1231 (1976)

Kärger, J., Bülow, M., Lorenz, P.: NMR self-diffusion measurements in $n$-heptane-benzene mixtures adsorbed on $\mathrm{NaX}$ zeolites. J. Colloid Interface Sci. 65, 181-185 (1978a)

Kärger, J., Bülow, M., Struve, P., Kocirik, M., Zikanova, A.: Intercrystalline molecular transport in zeolites studied by uptake experiments and by nuclear magnetic resonance pulsed field gradient techniques. J. Chem. Soc. Faraday Trans. I 74, 1210-1220 (1978b)

Kärger, J., Pfeifer, H., Rauscher, M., Walter, A.: Selbstdiffusion der homologen Reihe der $n$-Alkane von $n$-Butan bis $n$-Oktadekan in NaX-Zeolithen. Z. Phys. Chem., Leipz. 259, 784-790 (1978c)

Kärger, J., Pfeifer, H., Rauscher, M., Walter, A.: Self-diffusion of $n$-paraffins in NaX zeolite. J. Chem. Soc. Faraday Trans. I 76, 717-737 (1980)

Kärger, J., Pfeifer, H., Rauscher, M., Bülow, M., Samulevich, N.N., Zhdanov, S.P.: Comparative uptake and NMR studies of molecular transport of ethane in $5 \mathrm{~A}$ zeolites after different sample pretreatment. Z. Phys. Chem., Leipz. 262, 567-576 (1981)

Kärger, J., Krause, W., Pfeifer, H.: Intracrystalline diffusion in ZSM-5 zeolites. Z. Phys. Chem., Leipz. 263, 838-840 (1982) 
Kärger, J., Keller, W., Pfeifer, H., Ernst, S., Weitkamp, J.: Unexpectedly low translational mobility of methane and tetrafluoromethane in the large-pore molecular sieve VPI-5. Microporous Mater. 3, 401-408 (1995)

Kärger, J., Kortunov, P., Vasenkov, S., Heinke, L., Shah, D.B., Rakoczy, R.A., Traa, Y., Weitkamp, J.: Unprecedentend insight into diffusion by monitoring the concentration of guest molecules in nanoporous host materials. Angew. Chem., Int. Ed. Engl. 45, 7846-7849 (2006)

Naumov, S., Khokhlov, A., Valiullin, R., Kärger, J., Monson, P.A.: Understanding capillary condensation and hysteresis in porous silicon: network effects within independent pores. Phys. Rev. E 78, 060601(R) (2008)

Nestle, N., Galvosas, P., Zimmermann, C., Stallmach, F., Kärger, J.: Direct investigation of the fate of NAPL contaminations on a hydrating cement matrix by means of magnetic resonance techniques. Environ. Sci. Technol. 38, 880-885 (2004)

Pfeifer, H., Kärger, J., Germanus, A., Schirmer, W., Bülow, M., Caro, J.: Concentration dependence of intracrystalline self-diffusion in zeolites. Adsorption Sci. Tech. Phys. 2, 229-239 (1985)

Roethe, K.-P., Gutsche, R., Richter, W., Roethe, A., Caro, J., Kärger, J.: Adsorption of aromatics on silica gel. Adsorp. Sci. Technol. 3, 65-74 (1986)

Stallmach, F., Gröger, S., Künzel, V., Kärger, J., Yaghi, O.M., Hesse, M., Müller, U.: NMR studies on the diffusion of hydrocarbons on the metal-organic framework material MOF-5. Angew. Chem., Int. Ed. Engl. 45, 2123-2126 (2006)

Tzoulaki, D., Heinke, L., Schmidt, W., Wilczok, U., Kärger, J.: Exploring crystal morphology of nanoporous hosts from time-dependent guest profiles. Angew. Chem., Int. Ed. Engl. 47, 3954-3957 (2008a)

Tzoulaki, D., Schmidt, W., Wilczok, U., Kärger, J.: Formation of surface barriers on silicalite-1 crystal fragments by residual water vapour as probed with isobutene by interference microscopy. Microporous Mesoporous Mater. 110, 72-76 (2008b)

Zibrowius, B., Caro, J., Kärger, J.: Application of NMR spectroscopy to study diffusion anisotropy in polycrystalline samples. Z. Phys. Chem., Leipz. 269, 1101-1106 (1988) 